\title{
PROPERTIES AND STRUCTURE OF X30MnAISi26-4-3 HIGH STRENGTH STEEL SUBJECTED TO DYNAMIC COMPRESSION PROCESSES
}

\begin{abstract}
The paper presents the results of investigation on X30MnAlSi26-4-3 austenitic steel subjected to dynamic compression using the split Hopkinson pressure bar. The strain rate was $3700 \mathrm{~s}^{-1}$. The compression test was also carried out without the use of breaking rings and then true strain was about 0.3 . The split Hopkinson pressure bar test take only few milliseconds to complete during which time it is impossible to transfer the excess heat out of the specimen, therefore the test must be carried out in adiabatic conditions and so the increase of the temperature caused by the work of plastic deformation had to be calculated. The stepping load method was used in order to evaluate the effect of adiabatic heating on the properties of steel which allowed to maintain the isothermal deformation conditions. The paper presents the comparison of results obtained during deformation under adiabatic and isothermal conditions in correlation to structure changes occurring in course of dynamic compression.
\end{abstract}

Keywords: high strength steel, dynamic compression, split Hopkinson bar, share bands

\section{Introduction}

A favorable combination of strength and plastic properties, as well as very high ability to absorb deformation energy allows for assuming that the possibilities to use high Mn steels will be increasingly more common. Utilization of the particular mechanism of plastic deformation, namely mechanical twinning, may lead to an important change in possibilities of designing and production of structural elements protecting from effect of collision: in means of transport, in protective structures - during penetration with high speeds in aerospace and military technologies, and in cryogenics [1-3]. In order to reduce stroke g-forces, structural and protective elements having a direct contact with the obstacle, must exhibit such a deformability so as to absorb the highest collision energy possible. We witness a change in the approach to design of modern steels with a broad range of strength and plastic properties, including the high Mn steels from the group of steels hardened in the result of structural effects induced by plastic deformation [4-6]. The main alloying component controlling the stability of austenite during the deformation of the discussed steels is manganese. Based on a literature review, it was shown that in order to achieve favorable relations between strength and plasticity, being a consequence of the twinning mechanism, an optimum manganese content should amount to ca. $20 \div 35 \%$ by wt., aluminum content - ca. $3 \div 5 \%$ by wt., silicon content - up to $4 \%$ by wt., while contents of carbon and other elements should totalize to $0.003 \div 0.6 \%$ by wt.[7,8]. Contents the main alloying elements, i.e. manganese, silicon and aluminum, has should be have influence on the stacking fault energy (SFE) of the steel, and thus it is decisive in the definition of a prevailing deformation mechanism. Therefore, influencing the SFE turned out to be a process serving the purpose of intentional activation of the preferred deformation mechanism. That the principal factor decisive for both possibility and propensity of manganese steels for deformation hardening is deformation rate, since these materials belong to the group of alloys having particular sensitivity to this parameter $[9,10]$. Deformation rate is one of the basic parameters of plastic working process which may vary in a broad range, while the other parameters are constant or negligibly low. In this context, studies on materials may be carried out using a broad spectrum of deformation rates starting from the range of very low rates, up to the range of deformation rates higher than $10^{4} \mathrm{~s}^{-1}$. The latter values corresponds to tests with use of very high deformation rates obtained by generating plane waves. Determination of methods for deformation enabling realization of the deformation in a broad range of rates, from static conditions to very high rates, is of high importance. Carrying out of such tests may become a standard in studies on construction materials subjected to dynamic loads [11].

\section{Experimental procedure}

The research material was X30MnAlSi26-4-3 steel melted using vacuum induction furnace in ceramic pot and cast by

\footnotetext{
SILESIAN UNIVERSITY OF TECHNOLOGY, FACULTY OF MATERIAL SCIENCE AND METALLURGY, 40-019 KATOWICE, 8 KRASINSKIEGO STR., POLAND

** MOTOR TRANSPORT INSTITUTE, 03-301 WARSAW 80 JAGIELLOŃSKA STR., POLAND 
gravitational method. The resulting ingots were then rolled in a temperature range of $950 \div 1150^{\circ} \mathrm{C}$ into round bars of diameter $12 \mathrm{~mm}$. The bars were subjected to solutioning at a temperature of $1170^{\circ} \mathrm{C}$ which resulted in the formation of a stable austenitic structure with typical annealing twins. Dynamic compression test was carried out using cylindrical specimens of dimensions: height $h=5 \mathrm{~mm}$ and diameter $b=5 \mathrm{~mm}$. The strain rate value in the compression test was equal to $0.01,1400,2500$ and $3700 \mathrm{~s}^{-1}$. During high strain rate testing a modified split Hopkinson pressure bar method was used.

The test stand, presented in Fig. 1, was equipped with incident (8) and transmitter (9) bars $20 \mathrm{~mm}$ in diameter and $1000 \mathrm{~mm}$ in length, The signals acquired from the strain gauges (7) were amplified by the wideband bridge circuit (3) and digitized by an oscilloscope (4). The initial velocity of the striker (5), which was accelerated in a pressure gas launcher (1) was measured by two sets of diodes and photo detectors coupled to a digital counter (2). Based on the waveforms recorded by a digital oscilloscope for transmitted $\varepsilon_{T}(t)$ and reflected $\varepsilon_{R}(t)$ waves and the known cross sectional area of the bars $A$ and the specimen $A_{S}$, the speed of the elastic wave propagation in the material of the bars $C_{0}$ and the test-piece length $L$, it is possible to determine stress $\sigma(t)$, strain $\varepsilon(t)$ and strain rate $\varepsilon(t)$ in the specimen using the following formulas [12]:

$$
\begin{gathered}
\sigma(t)=E\left(\frac{A}{A_{S}}\right) \varepsilon_{T}(t) \\
\varepsilon(t)=-\frac{2 C_{0}}{L} \int \varepsilon_{R}(t) d t \\
\dot{\varepsilon}(t)=\frac{d \varepsilon(t)}{d t}=\frac{-2 C_{0}}{L} \varepsilon_{R}(t)
\end{gathered}
$$

Schematic outline of the split-Hopkinson pressure bar tester was shown on Fig. 1

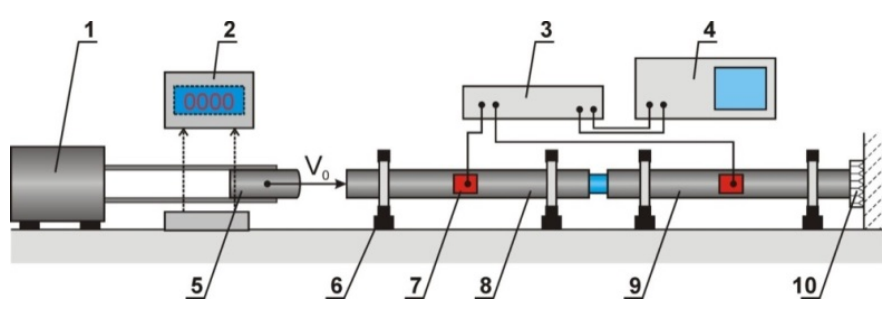

Fig. 1. Split Hopkinson tension bar testing system; 1 - pneumatic launcher, 2 - optoelectronic system of speed measurement, 3 - strain gauge, 4 - digital oscilloscope , 5 - momentum trap bar, 6 - bearing, 7 - extensometer, 8 -incident bar, 9 - transmitter bar, 10 - damper [22]

After testing the properties of the steel under conditions of dynamic deformation the structure analysis employed the techniques of light microscopy and scanning transmission electron microscopy. Analysis of misorientation in selected areas was performed using diffraction images (so-called nanodiffraction). Diffraction measurements for neighbouring grains were carried out to determine the zonal axis. Interplanar angles of regular system used to estimate the misorientation angles were calculated from equation (4) [13]:

$$
\cos \phi=\frac{h_{1} h_{2}+k_{1} k_{2}+l_{1} l_{2}}{\sqrt{h_{1}^{2}+k_{1}^{2}+l_{1}^{2}} \times \sqrt{h_{2}^{2}+k_{2}^{2}+l_{2}^{2}}}
$$

Diffraction of the individual grains was performed with identical arrangement of the sample relative to the electron beam.

\section{Results and discussion}

Stress-strain characteristics of the X30MnAlSi26-4-3 steel after dynamic cold compression test with strain rate of $3700 \mathrm{~s}^{-1}$ are shown in Figures 2 and 3. In order to evaluate the influence of adiabatic heating that occurs in the high-speed deformation process on the properties of the steel sample the stepped load method was used. It consists of deformation of the sample in several stages, between which it returns to the starting temperature. Then, taking into account the deformation history, the origin points of characteristics are combined, so that it becomes possible to plot the compression curve and compare it with the results obtained under adiabatic conditions (Fig. 2). Stepped deformation test was carried out by strain reduction to known value of 0.1 after which the thermal conditions were stabilised during $1800 \mathrm{~s}$ time before the next compression. The steps were repeated to obtain a true strain degree equal 0.3 (Fig. 3).

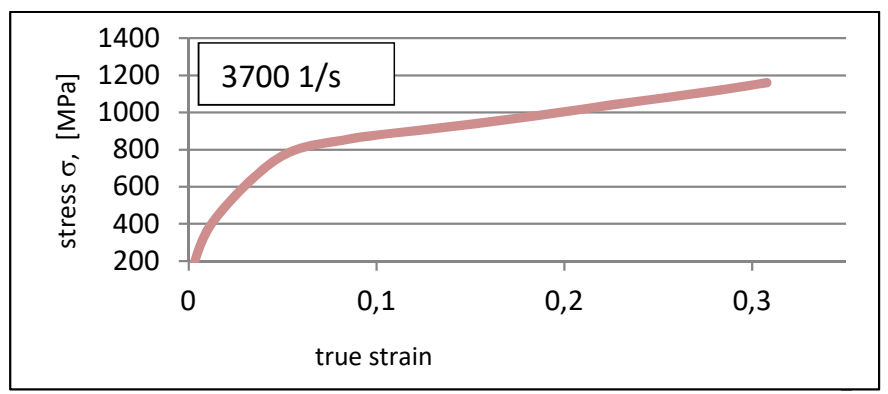

Fig. 2. Stress-strain characteristic of X30MnAlSi26-4-3 steel after dynamic compression test with strain rate $3700 \mathrm{~s}^{-1}$

Under adiabatic conditions the stress increase is continuous with increasing true strain value. At isothermal conditions, assuming a constant processing temperature, the stress increases to 0.06 and then remains constant (Fig. 3). Under isothermal conditions resulting from steeped deformation carried out like presented in Figure 3 the X30MnAlSi26-4-3 steel shows very different properties than those recorded under adiabatic conditions (Fig. 2).

The temperature increase is inevitable during deformation at high strain rates because the deformation time is very short and there is no possibility transfer the excess heat out of the sample by convection, radiation or conduction $[10,12]$. The temperature rise due to work required for the plastic deformation of the specimen was determined using the formula (5) [14]: 


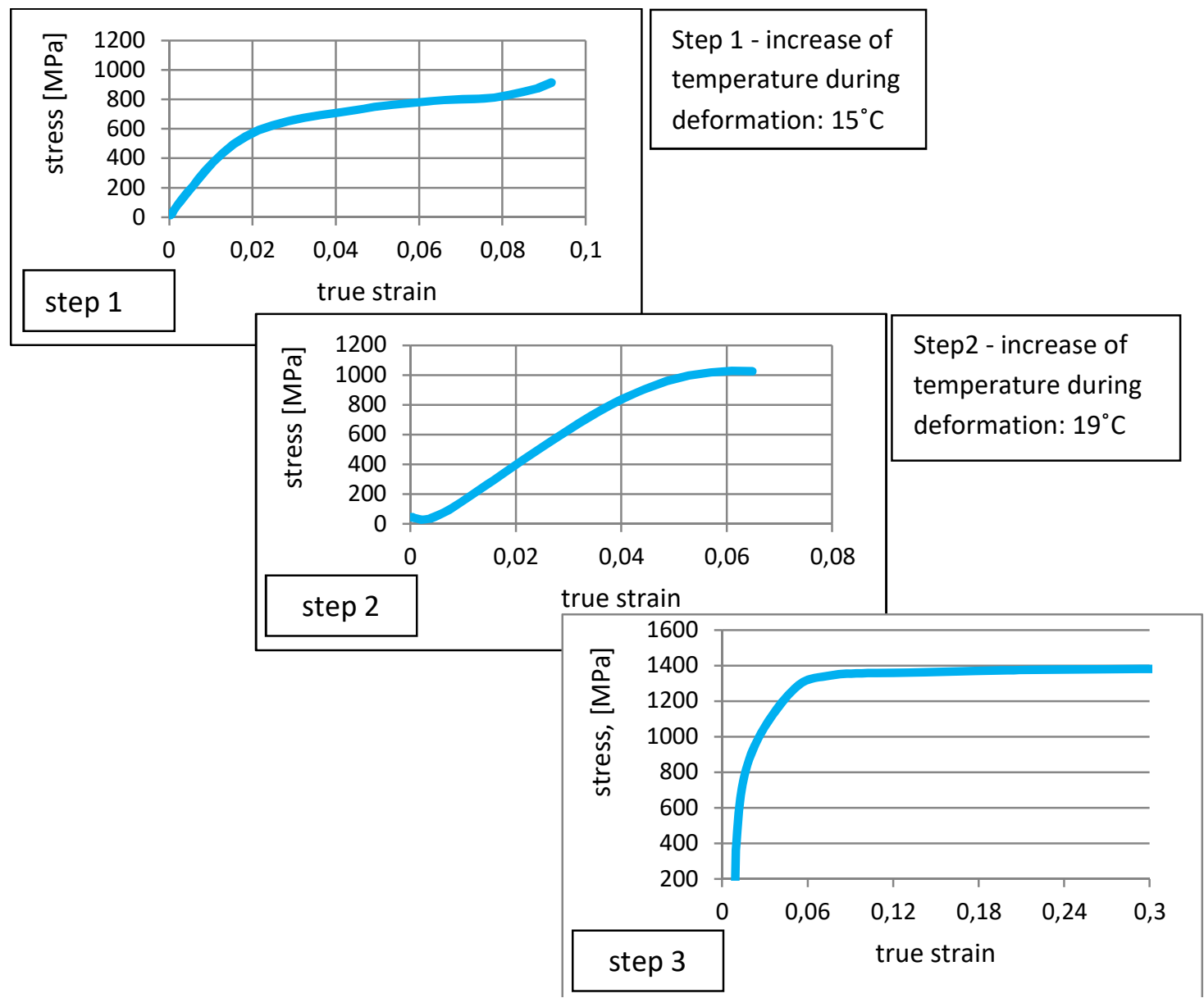

Fig. 3. Stress-strain characteristic of X30MnAlSi26-4-3 steel after dynamic compression test with strain rate $3700 \mathrm{~s}^{-1}$ using the stepped deformation method

$$
\Delta T=\frac{\beta}{\rho \times C_{V}} \int_{0}^{\varepsilon_{\max }} \sigma d \varepsilon
$$

where:

$\beta$ - Taylor-Quinney coefficient which describes the workheat conversion, it is typically 0.9 ,

$\rho-$ density of the material, $7.8 \mathrm{~g} / \mathrm{cm}^{3}$,

$C v$ - specific heat of steel, $0.46 \mathrm{~kJ} / \mathrm{kg} \cdot{ }^{\circ} \mathrm{C}$

During compression at a strain rate of $1400 \mathrm{~s}^{-1}$ the temperature have increased by $55^{\circ} \mathrm{C}$, at a rate of $2400 \mathrm{~s}^{-1}$ by $65^{\circ} \mathrm{C}$ and with strain rate of $3700 \mathrm{~s}^{-1}$ the temperature have increased by $77^{\circ} \mathrm{C}$. The data of temperature rise due to the conversion of work needed for the plastic deformation of high-manganese steels has been published in works $[14,15]$. In [14] the reported increase in temperature was $95^{\circ} \mathrm{C}$ during dynamic tensile test of TWIP steel at strain rate of $1250 \mathrm{~s}^{-1}$ and in [16] the increase was $17^{\circ} \mathrm{C}$ during compression at rate of $700 \mathrm{~s}^{-1}$ and $54^{\circ} \mathrm{C}$ at $2500 \mathrm{~s}^{-1}$, the presented data are similar to the results obtained in this work.

High strain rate leads to the local instability of the material in the form of shear bands $[17,18]$. Shear bands are areas of high strain energy accumulation [18]. $450 \mathrm{~nm}$ wide adiabatic shear bands with high misorientation in respect to the matrix were found after compression at a rate of $3700 \mathrm{~s}^{-1}$ and true strain value of 0.3 (Fig. 4). Revealed bands were characterized by large mutual misorientation (Fig. 5). Ultrafine grains free of dislocations has been observed inside the bands. The occurrence of high misorientation is the result of intensive accumulation of dislocations within the band [19-22]. Similar structural effects were also observed in [21-23].

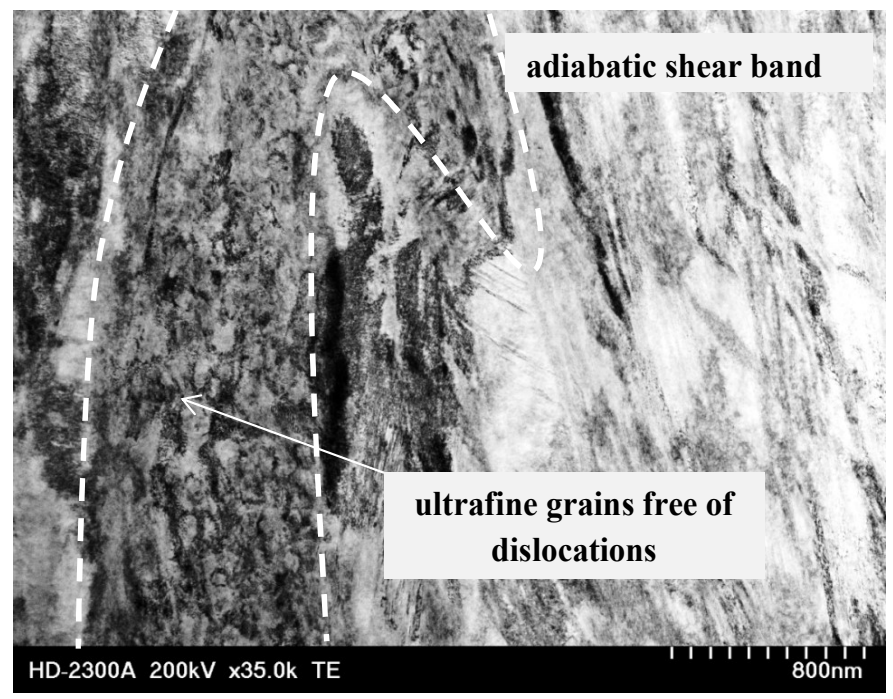

Fig. 4. Substructure of X30MnAlSi26-4-3 steel after compression with strain rate of $3700 \mathrm{~s}^{-1}$ and stress value of 0.3 ; Adiabatic shear band 


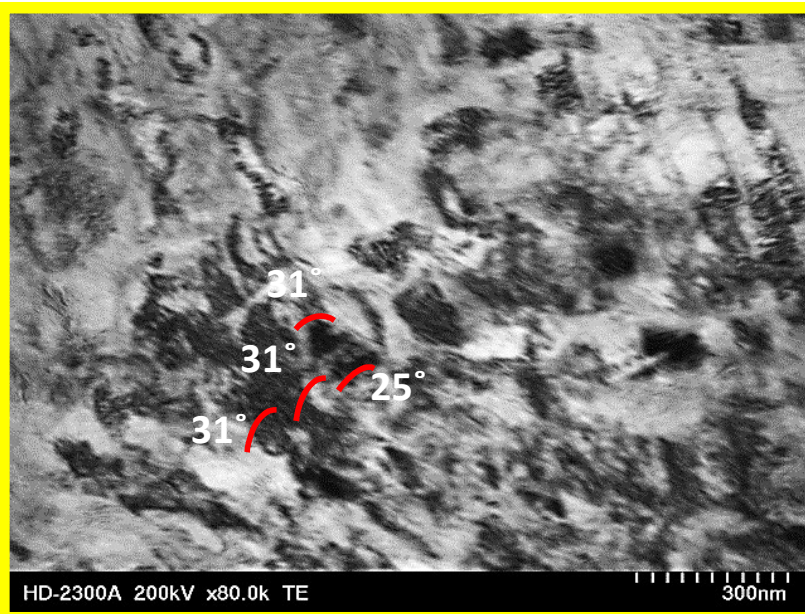

a)
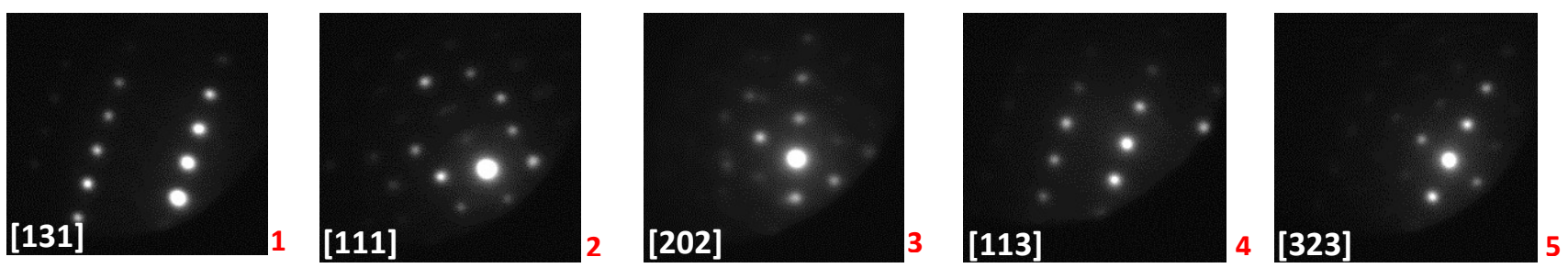

Fig. 5. Substructure of X30MnAlSi26-4-3 steel after compression with strain rate of $3700 \mathrm{~s}^{-1}$ and stress of 0.3 ; part of the area with subgrains that form the adiabatic shear band on Fig. 5; a) light field; b) dark field; c) diffractions of areas in Fig. 5

Structure of steel deformed using steeped method indicate that the deformation is realised with high proportion of dislocation slip (Figs. 6,7). Under cold compression conditions used deformation of the material takes place mainly as a result of the formation shear micro-bands in which the strain is concentrated. The dislocation walls responsible for the compensation of the strain gradient between adjacent grains were also present in the structure. In addition to the above phenomena microanalysis revealed the occurrence of deformation twins in the simple system (Fig. 6) and stacking fault (Fig. 7).

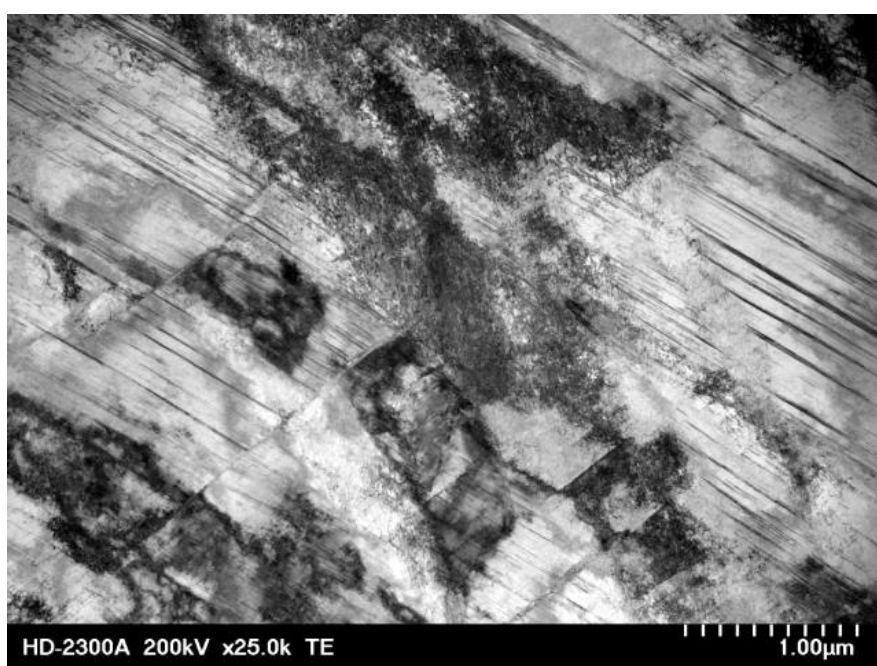

Fig. 6. Substructure of X30MnA1Si26-4-3 steel after compression with strain rate of $3700 \mathrm{~s}^{-1}$ and stress value of 0.3 under isothermal conditions; shear micro-bands; deformation twins; shear bands

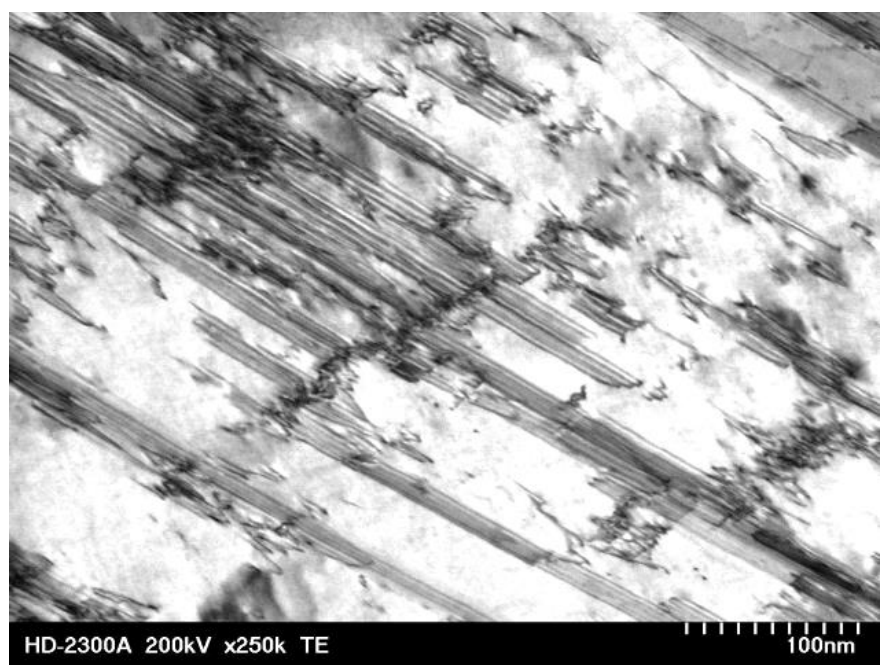

Fig. 7. Substructure of X30MnAlSi26-4-3 steel after compression with strain rate of $3700 \mathrm{~s}^{-1}$ and stress value of 0.3 under isothermal conditions; stacking fault created by partial dislocations

Because of the possible application of tested steel for manufacturing of parts that absorb the energy of plastic deformation in automotive industry the energy absorbed during dynamic compression test was measured under isothermal and adiabatic conditions. The value of the plastic deformation work relative to the volume of the sample was defined as the specific energy absorption index (SEA) and calculated using the formula [24]:

$$
S E A=\frac{\int \sigma d \varepsilon}{V} \mathrm{~J} / \mathrm{mm}^{3}
$$




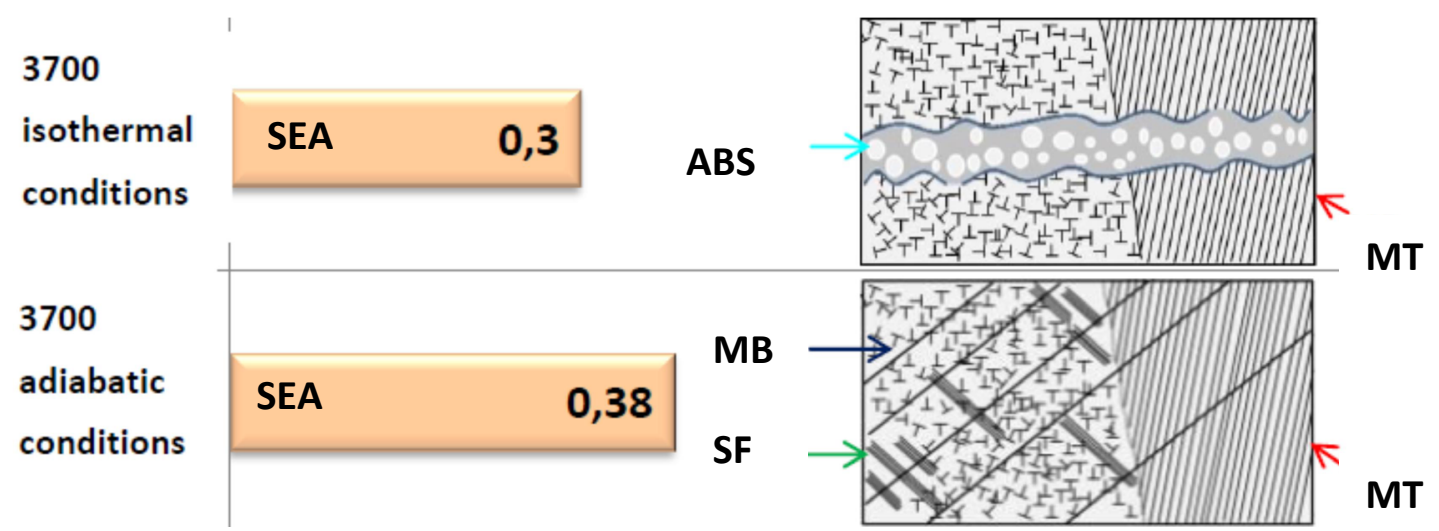

Fig. 8. An index value of specific energy absorption of the SEA with flow diagram structure changes depending on the isothermal and adiabatic conditions of dynamic deformation in a compression test for X30MnAlSi26-4-3 steel; MB - micro bands, MT - mechanical twinning, ABS - adiabatic shear band, SF - stacking fault

Figure 8 summarizes the values of energy absorption index for X30MnAlSi26-4-3 steel determined at a deformation rate of $3700 \mathrm{~s}^{-1}$. The SEA index value was presented in comparison with the structure change diagrams prepared using data obtained by scanning transmission electron microscopy.

The tested steel demonstrated the ability to store the energy of plastic deformation. The SEA index calculated for given deformation conditions was 0.3 and $0.38 \mathrm{~J} / \mathrm{mm}^{3}$ in adiabatic and isothermal conditions respectively. So high SEA index value is an effect of participation of shear micro-bands and deformation twins in plastic deformation.

\section{Conclusions}

During deformation under high strain rates the sample temperature increases as a result of the work-heat conversion which makes it necessary to correct the stress-strain curves. It was calculated that during the process the temperature increase reach the maximum value of $77^{\circ} \mathrm{C}$ depending on the strain rate. Temperature increase values are comparable to literature data. Under adiabatic conditions the stress-strain curves indicate the continual increase in stress. Use of stepped deformation method, which brings the process closer to isothermal conditions, changed the compression curves character. In the initial stage of the compression the stress increases and then stabilizes after reaching the true stress value of 0.06 . Research shows that the temperature rise during the experiment does not affect the change in the structure of the tested steel. Under adiabatic conditions, the adiabatic plastic deformation bands were observed which is common in dynamic deformation. Adiabatic shear bands show non-crystallographic structure course and their formation is initiated by the structural heterogeneity. The X30MnAlSi26-4-3 steel exhibits an ability to store the deformation energy, expressed by the index of specific energy absorption (SEA). After the dynamic tensile tests with a rate of $3700 \mathrm{~s}^{-1}$ in adiabatic conditions, the SEA value amounted to $0.3 \mathrm{~J} / \mathrm{mm}^{3}$, while in the compression tests, the SEA value amounted to $0.38 \mathrm{~J} / \mathrm{mm}^{3}$ at the rate of $3700 \mathrm{~s}^{-1}$ in isothermal conditions.

\section{Acknowledgements}

Financial support of BK-263/RM3/2016 is gratefully acknowledged.

\section{REFERENCES}

[1] O. Bouaziz, S. Allain, C.P. Sccot, P Cugy, D. Barbier, High manganese austenitic twinning induced plasticity steels, A review of the microstructure properties relationships, Curr. Opin. Solid St. M 15 (4), 141-168 (2011).

[2] P.S. Kusakin, R.O. Kaibyshev, High-Mn Twinning-Induced Plasticity Steels, Microstructure and Mechanical Properties, Rev. Adv. Mater. Sci. 44, 326-360 (2016).

[3] G. Niewielski, D. Kuc, Stal dla przemysłu motoryzacyjnego. Praca zbiorowa pod red. W. Szkliniarza pt. Nowoczesne materiały metaliczne - teraźniejszość i przyszłość, Wydział Inżynierii Materiałowej i Metalurgii Politechniki Śląskiej, Katowice (2009).

[4] O. Grassel, L. Kruger, G. Frommeyer, L.W. Meyer, High strength Fe-Mn-(Al, Si) TRIP/ TWIP steel development - properties - application, Int. J. Plast. 16, 1391-409 (2000).

[5] A. Śmiglewicz, W. Moćko, R. Rodak, I. Bednarczyk, M.B. Jabłońska, Study of Dislocation Substructures in High-Mn Steels after Dynamic Deformation Tests, Acta Phys. Pol. A 130 (4), 942-945 (2016).

[6] S. Curtze, V.T. Kuokkala, M. Hokka, P. Peur, Deformation behavior of TRIP and DP steels in tension at different temperatures over a wide range of strain rates, Mater. Sci. Eng. A 507 (1), 124-131 (2009).

[7] K.T. Park, K.G. Jin, S.H. Hanb, S.W. Hwang, K. Choi, C.S. Lee, Stacking fault energy and plastic deformation of fully austenitic high manganese steels, Effect of Al addition, Mater. Sci. Eng. A 527, 3651-3661 (2010).

[8] X. Tian, Y. Zhang: Effect of Si content on the stacking fault energy in $\gamma$-Fe-Mn-Si-C alloys: Part II. Thermodynamic estimation, Mater. Sci. Eng. A 516 1-2, 73-77 (2009).

[9] L. Da-zhao, W. Ying-hui, L. Chun-yue, H. Li-feng, L. Dong-Ieng, I. Xian-zhe, Effects of High Strain Rate on Properties and Micro- 
structure Evolution of TWIP Steel Subjected to Impact Loading, Journal of Iron And Steel Research International 17 (6), 2010

[10] W.P. Bao, Z.P. Xiong, F.M. Wang, J. Shu, X.P. Ren, Comparison of dynamic mechanical properties between Pure Iron (BCC) and Fe-30Mn-3Si-4Al TWIP Steel (FCC), Appl. Mech. Mater. 692, 179-186 (2014)

[11] A. Śmiglewicz, M.B. Jabłońska, The effect of strain rate on the impact strength of the high-Mn steel, Metalurgija 54 (4), 631-634 (2015).

[12] W. Moćko, L. Kruszka, Results of strain rate and temperature on mechanical properties of selected structural steels, Procedia Engineering 27, 789-797 (2013).

[13] K.W. Andrews, D.J. Dyson, S.R. Keown, Interpretation of electron Diffraction patterns, (ed.) Adam Hilger LTD, London 1971.

[14] S. Curtze, V.T. Kuokkala, Effects of temperature and strain rate on the tensile properties of TWIP steels, Revista Materia 15 (2), 157-163 (2010)

[15] Z.P. Xiong, X.P. Ren, W.P. Bao, S.X. Li, H.T. Qu, Dynamic mechanical properties of the Fe-30Mn-3Si-4Al TWIP steel after different heat treatments, Mater. Sci. Eng. A 530, 426-431 (2011).

[16] W. Moćko, Z.L. Kowalewski, A. Wojciechowski, D. Rudnik, Badania właściwości mechanicznych staliwa LH556 i stali VP159 pod kątem zastosowania w osłonach balistycznych, Biuletyn WAT 61, 449-462 (2012)

[17] B. Leszczyńska, M. Richert, Wpływ dużych prędkości odkształcenia na własności mechaniczne i rozdrobnienie struktury w aluminium i miedzi, Rudy i Metale Nieżelazne 10-11, 2005.
[18] H. Paul, Mikroteksturowe uwarunkowania procesu rekrystalizacji pierwotnej w metalach o sieci A1, Wydawnictwo PAN, Kraków (2002).

[19] J.F.C. Lins, H.R.Z. Sandim, H.J. Kestenbach, D. Raabe, K.S Vecchio, A microstructural investigation of adiabatic shear bands in an interstitial free steel, Mater. Sci. Eng. A 457 (1), 205-218 (2007).

[20] N. Bassim, J. Delorme, Modelling of Formation of Adiabatic Shear Bands, Appl. Mech. Mater. 566, $92-96$ (2014).

[21] H. Wang, X. Sun, P. Yang, W. Mao, Inspection of adiabatic shear bands in high manganese TRIP steels, Mater. Sc.i Forum 753, 72-75 (2013)

[22] M.B. Jabłońska, A. Śmiglewicz, G. Niewielski, M. Hetmańczyk, Heat treatment of high manganese type X57MnAl27-5 austenitic steel, Technologies and Properties of Modern Utilised Materials: IOP Conference Series, Mater. Sci. Eng. 22, 1-6 (2011).

[23] P. Sahu, S. Curtze, A. Das, B. Mahato, V.T. Kuokkala, S.G Chowdhury, Stability of austenite and quasi-adiabatic heating during high strain-rate deformation of twinning-induced plasticity steels, Scripta Mater. 62 (1), 5-8 (2010).

[24] A. Śmiglewicz: Struktura i właściwości stali wysokomanganowej kształtowane w wyniku mechanicznego bliźniakowania indukowanego odkształceniem plastycznym $\mathrm{PhD}$. Thesis Silesian University of Technology (2015). 